\title{
Morphological evolution of a barchan dune migrating past an offshore wind farm foundation
}

\section{Amelia Couldrey, Thomas Benson, Michiel Knaapen, Kerry Marten and Richard Whitehouse}

HR Wallingford, Howbery Park, Wallingford, Oxfordshire OX10 8BA, UK

Corresponding author: Amelia Couldrey, a.couldrey@hrwallingford.com.

Published in Earth Surface Processes and Landforms, Early View (2020)

Please note, the version below is as 'Submitted'.

\section{Abstract}

As the number of manmade structures installed on the seafloor is increasing rapidly, we seek to understand the impact of these immobile obstacles on marine geomorphological processes, such as the evolution of bedforms. A $5.8 \mathrm{~m}$ diameter monopile foundation was installed at the case study offshore windfarm approximately $30 \mathrm{~m}$ ahead of an approaching barchan (crescent-shaped) dune. The impact of the monopile on the dune's evolution was analysed using six multibeam bathymetry surveys spanning 20 years. To substantiate this analysis, coupled three-dimensional numerical modelling of flows and sediment was conducted in which the scour inducing bed shear stresses were calculated from the modelled turbulent kinetic energy. Following the installation of the monopile, the mid-section of the dune accelerated and stretched in the direction of the wake of the monopile. Four years after the monopile's installation the rest of the dune had caught up, flattening out the slip face within half the dune's length downstream of the monopile. Due to the modified flow field, the dune was scoured deeply at the base of the monopile to a depth of $6.8 \mathrm{~m}$ (supported by the model results that predicted a scour depth exceeding $2 \mathrm{~m}$ over a period of just a few days). The surveyed volume of material scoured amounted to $8 \%$ of the total dune volume. Whilst the process of scouring occurs at a timescale of days to weeks, the dune migrated on average by $25 \mathrm{~m} / \mathrm{yr}$. The difference in the timescale of the two processes allowed the scouring to occur through the full thickness of the dune. The scoured dune profile recovered rapidly once the dune migrated downstream of the monopile. This article demonstrates how large geomorphological features can intercept and migrate past a monopile foundation without long-lasting impacts on the integrity of the feature or the foundation.

\section{Keywords}

marine geomorphology; barchan dune; multibeam bathymetry; sediment transport; scour; offshore wind farm 


\section{Introduction}

There are currently more than 1,900 offshore wind farm foundations in UK waters, with approximately 900 additional foundations under construction (The Crown Estate, 2019). Because of the increasing number of structures being installed onto or into the seabed and, subject to the safeguards of environmental impact studies, there is an increased potential for these immobile obstacles to be placed in the pathways of naturally migrating marine dunes. Consequently, it is becoming increasingly important to have an understanding of the interactions between marine dunes and structures installed on the seafloor.

The interaction between linear sandwaves with submerged objects, e.g. a cylindrical bridge pier or monopile foundation, has been studied through physical (Chiew 1984; Hong et al., 2017) and numerical (Margalit, 2017) modelling. Primarily these studies are concerned with the interaction between the dune and the scour at the base of the foundation. Scour is the process by which flow past an obstacle (in this case a monopile) is altered, initiating flow acceleration and an increase in turbulent intensity, which in turn leads to the transport and removal of sediment (Whitehouse, 1998).

In Hong et al.'s (2017) work, linear dunes were created in a live-bed sediment transport experiment. The dunes migrated along the flume and interacted with a cylindrical pier with a scour hole already formed in a sand bed. The pile was $0.07 \mathrm{~m}$ diameter and the water depth varied from 0.16 to $0.19 \mathrm{~m}$. The dune height was not stated, but led to fluctuations in scour depth of 0.3 pile diameters in one of their tests. Due to changes in the mean bed-level caused by the dune migration, the scour was shallower when the crest was at the pile and deeper when the trough was at the pile. Hong et al. (2017) showed a five-stage process for dune migration around a pier, building on Chiew's (1984) study. As the dune approaches the scour hole, the midsection is drawn into the scour hole and the rest of the plan shape of the dune is unaffected. As the dune encroaches on the scour hole, local vortex action and flow acceleration produces a stretching of the dune crest and a spatial lag as the dune adjacent to the monopile advances beyond the rest of the dune crest. As the dune enters the wake region of the monopile it slows down, allowing the rest of the dune to catch up. The dune reverts to its original shape and size about half a dune length downstream.

In Margalit's (2017) numerical model a monopile (of diameter $6 \mathrm{~m}$ in $12 \mathrm{~m}$ water depth) was placed within a field of sandwaves with initial heights of $3 \mathrm{~m}$ and lengths of $300 \mathrm{~m}$. It was observed that by blocking the sediment transport, material built up on the upstream side of the obstacle. This is likely due to the model not being setup to allow for local scouring, which would naturally accelerate the passage of this material. This is the opposite of the relationship observed in physical modelling of Hong et al. (2017), where the presence of the monopile accelerated transport on the lee side. In Margalit's (2017) numerical model downstream of the monopile, in the wake of the structure, a depression formed into the bedform crest where the sediment transport pathway was obstructed.

In both the study of Margalit (2017) and Hong et al. (2017) a linear bedform was considered, where the transport in the direction of the prevailing flow is continuous along the whole length of the bedform. This is not the case for all dunes, such as a crescent-shaped barchan dune (Figure 1), over which material is transported from the toe of the dune to the horns. The impact of a fixed structure on the transport pathway of a barchan dune will likely be dependent on the alignment of the dune with the obstacle, and on the relative sizes of the obstacle and dune. For barchan dunes specifically, the impact of an obstacle on the dune's migration pathway has not been documented in scientific literature. 


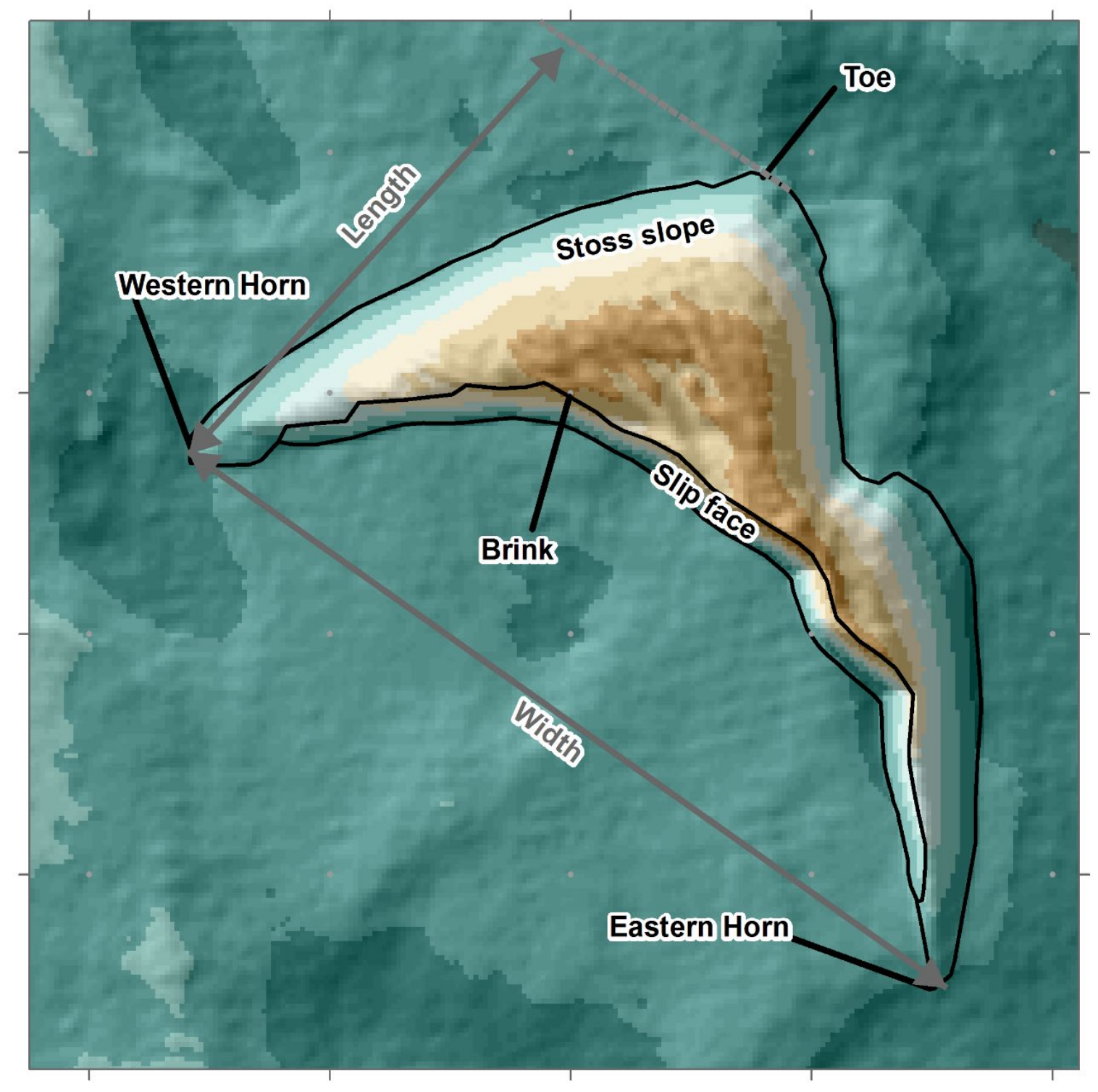

Figure 1. Key nomenclature used to describe a barchan dune. In this example the residual flow direction is from the top right towards the bottom left.

At offshore wind farm sites monopiles are driven into the seabed to create foundations on top of which wind turbine generator towers are installed. When designing a foundation its embedment depth is taken into consideration, since the overburden of the surrounding seabed material will affect the structure's stiffness and, consequently, its dynamic response (Mayall et al., 2019). This overburden can either increase due to the temporary shoaling of bed-levels at the base of a foundation when a bedform crest reaches a structure, or reduce through the removal of material at the base of the structure by scouring or general seabed lowering.

Marine barchan dunes are of particular interest to the management of offshore wind farm foundations since these dunes are both fast moving, migrating between 10 to 20 metres a year (Berné et al., 1989; Ernstsen et al., 2005; Ma, Yan, \& Fan, 2014) and are large, with crest heights that can exceed $8 \mathrm{~m}$ (Ma et al., 2014). Uniquely, these bedforms do not interact with the underlying seabed; as such they will not have a lowering 
effect on the general level of the bed (unlike linear bedforms). It has also been suggested that these dunes have the potential to host a rich biodiversity in their troughs (Van Lancker et al., 2013). However, this may be particular to large or very large dunes, the slower-migrating barchanoid-type dunes and/or those with protected troughs sheltered by a neighbouring dune.

Whilst barchan dunes migrate at a rate of approximately 10 to $20 \mathrm{~m} / \mathrm{yr}$, scour into loose sands can take place down to several metres with a timescale of a few days to weeks, potentially occurring within a few tidal cycles (Harris \& Whitehouse, 2015). Noormets et al. (2006) studied the scour taking place around a $1.65 \mathrm{~m}$ diameter pile located in a field of bedforms within a tidal inlet. They showed that the 0.25 to $0.4 \mathrm{~m}$ high dunes responded to spring-neap and seasonal changes in tidal forcing and found that scour at the pile responded almost instantaneously to changes in flow and the spring-neap cycle. Given the large scale of the barchan dune, and hence its residence time at a monopile, it is predicted that scouring will take place into the barchan as it migrates past the monopile. It is anticipated that the dune's presence will not dramatically alter the stability, and consequently performance, of the wind turbine; however, it is possible that the presence of the monopile will affect the dune morphology.

From this appraisal of current scientific knowledge, two main aims of this study are identified:

1. To analyse and explain the morphological evolution of a barchan dune as it passes an obstacle (a monopile foundation) and to determine if the presence of the obstacle has an impact (short or long term) on the dune's morphology.

2. To assess the impact of the passing dune on the sedimentary processes (e.g. scouring) at the base of the monopile.

\subsection{Definition of terms}

A barchan dune forms when the current (or wind) cannot set in motion all sedimentary particles or when there is a sand deficit. They can form under either a uni-directional current or a bi-directional current with a strong asymmetry. The terminology used to describe the dune morphology is defined in Figure 1. Material is transported from the toe of the dune up the stoss slope and is then deposited on the slip face as a result of separation eddies that form in the recirculation zone downstream (Bristow et al., 2019). The result is a net migration towards the direction that the horns point. Commonly, barchan dune dimensions are described by their horn-to-horn distance (width), horn-to-toe distance (length) and height (flat bed to top of crest).

\section{Study area}

\subsection{Infrastructure}

The study area is in a (non-disclosed) wind farm development off the east coast of the UK in the North Sea. In this study we will consider a single monopile foundation, with an outer diameter of $5.8 \mathrm{~m}$ and the area of seafloor approximately 200 by $200 \mathrm{~m}$ around it. The monopile was installed in December 2010 approximately $30 \mathrm{~m}$ ahead of a naturally migrating barchan dune using a self-propelled, four-legged self-elevating jack-up vessel.

The wind turbine generator is connected to two neighbouring foundations through two seabed-installed, inter-array electricity cables that lead out of the foundation towards the northwest and southwest. Scour protection (e.g. rock armour) has not been installed at this foundation and so, in line with the adopted design approach, scouring is free to take place into the sediment at the base of the foundation. 


\subsection{Site conditions}

The seabed level at the case study site is on average $-24.7 \mathrm{~m}$ relative to the Lowest Astronomical Tide (LAT). Locally to the dune, the seafloor slopes gradually $\left(<0.2^{\circ}\right)$ down towards the northeast. The spring tidal range in the region is approximately $3.4 \mathrm{~m}$ (meso-tidal), and the site is tidally dominated with flow towards the northeast during the ebbing phase and to the southwest during the flooding phase. Tidal current speeds are asymmetric and stronger on the flood phase. On average, bed current speeds are approximately 0.4 $\mathrm{m} / \mathrm{s}$, whilst peak current speeds are approximately $1 \mathrm{~m} / \mathrm{s}$. Currents during spring tides are on average between 0.1 and $0.2 \mathrm{~m} / \mathrm{s}$ stronger than neap tides.

The directional distribution of incoming waves is strongly bimodal (Figure 2) and proximally aligned with the tidal flow, with waves approaching from both the north-northeast and south-southwest. The largest waves approach the site from the north-northeast, with a 1 in 1 year significant wave height of $4.0 \mathrm{~m}$ (Figure 3).

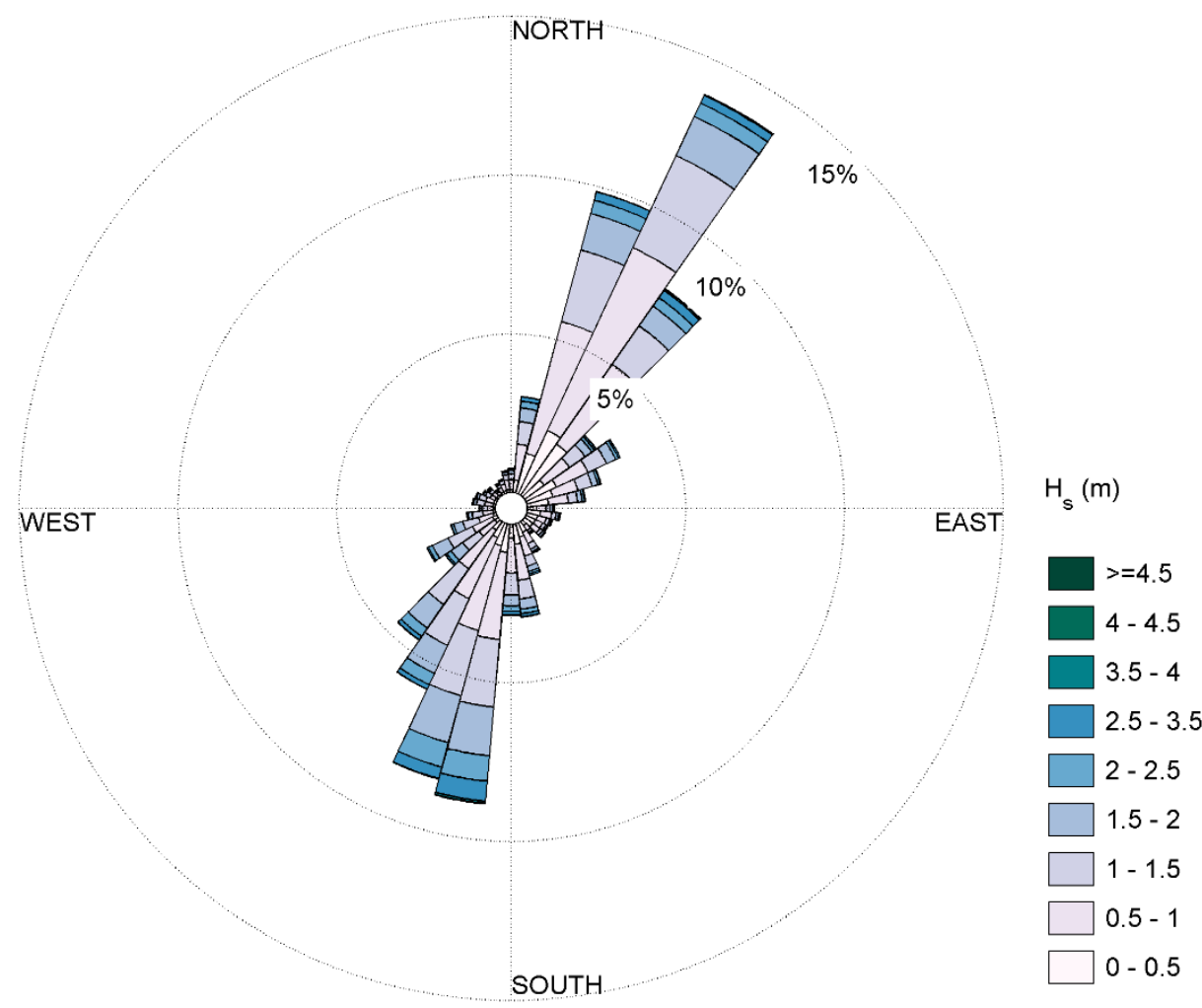

Figure 2. Directional distribution of significant wave heights, for 2002 - 2015, at location $20 \mathrm{~km}$ northnortheast from study area. The direction shown indicates the direction from which waves approach. 
To the northwest of the study barchan, aligned sub-parallel to the tidal currents, is a north-northeast to southsouthwest aligned linear sand ridge (Figure 4). This feature has a maximum height of $18 \mathrm{~m}$ relative to the ambient seabed level. Residual tidal currents, to the northeast on the western side and southwest on the eastern side, result in a clockwise circulation around the sand ridge. The sand ridge comprises well-sorted medium sands, with median grain sizes (d50) of about $0.35 \mathrm{~mm}$, whilst the surrounding seabed comprises mostly poorly sorted sands and gravelly sands, with median grain sizes between 0.50 and $0.75 \mathrm{~mm}$. This material forms a surface veneer generally not exceeding $1 \mathrm{~m}$ thickness overlaying firm to stiff clay.

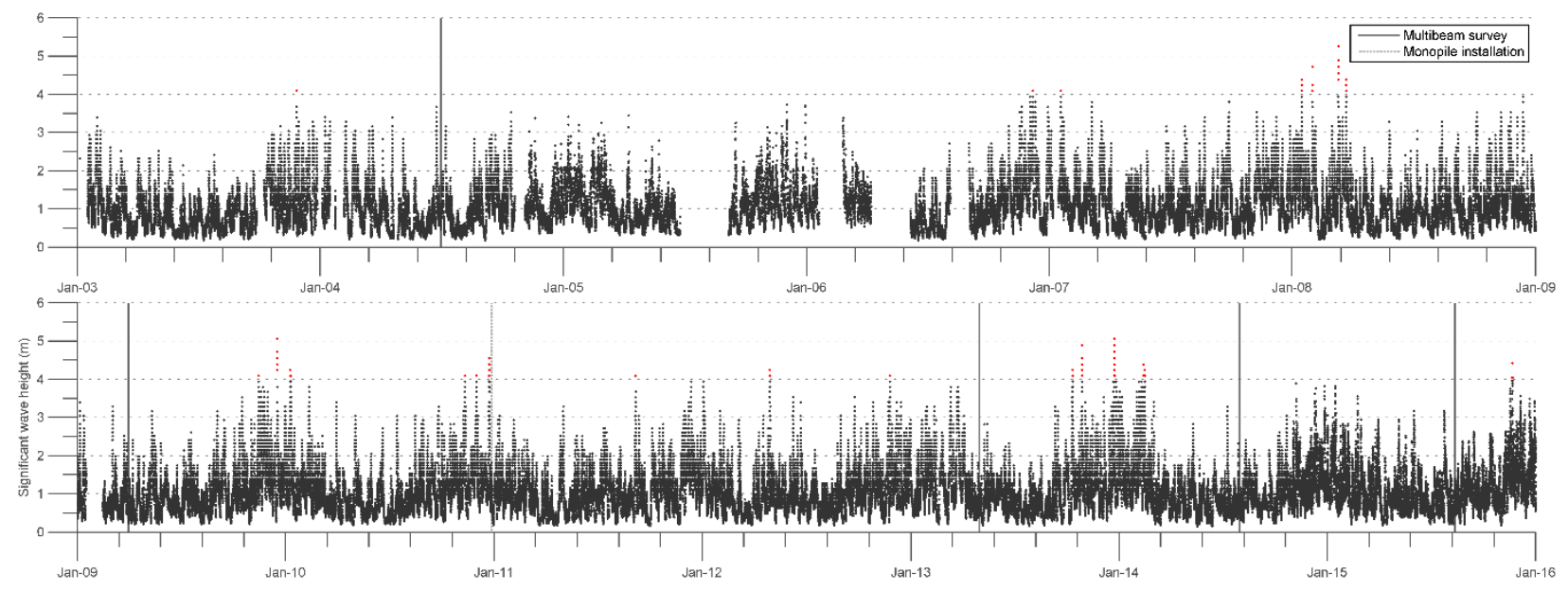

Figure 3. Time-series of significant wave heights from 2003 up to the end of 2015. Storm events (significant wave heights $>4 \mathrm{~m}$ are highlighted in red). 


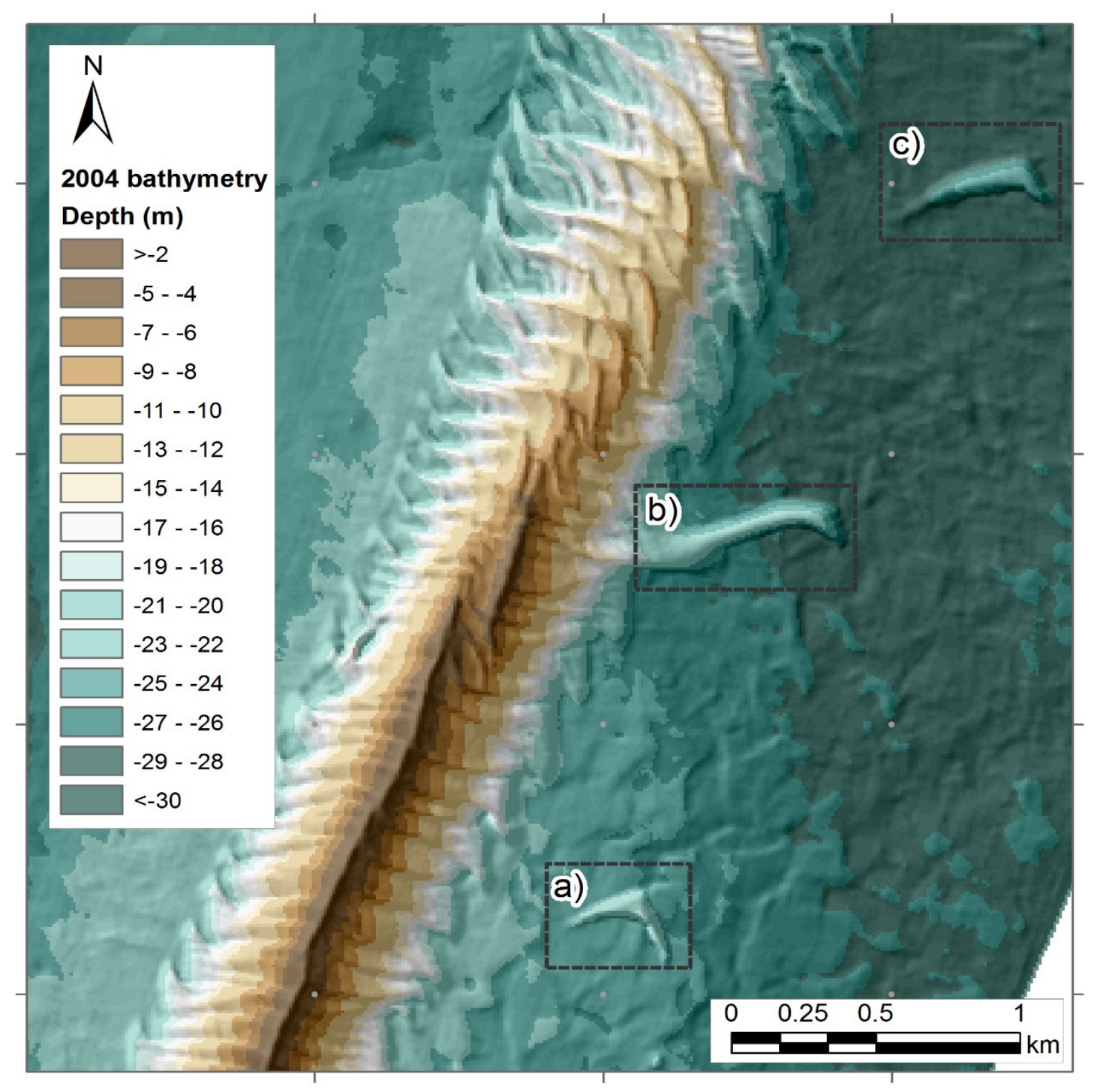

Figure 4. Overview of sand ridge and position of a) study barchan dune and two further dunes b) $1.8 \mathrm{~km}$ and c) $3.2 \mathrm{~km}$ to the north-northeast of the study dune. 


\section{Methods}

\subsection{Bathymetric surveys}

Six bathymetric surveys were available for analysis. Five of these (the 2004, 2009, 2013, 2014 and 2015 surveys) were collected using a multibeam echosounder for commercial operations related to the wind farm development and operation. These surveys had a total vertical uncertainty of $\pm 0.3 \mathrm{~m}$ or less. The horizontal $(x, y)$ resolution of the gridded data ranged between $10 \mathrm{~m}$ (2004) and $0.5 \mathrm{~m}$ (2014 and 2015). These surveys were all performed between late spring and summer.

The 1995 data, which were collected using a singlebeam echosounder, were sourced from the Admiralty Marine Data Portal (https://data.admiralty.co.uk/portal/). These data likely have a larger vertical and horizontal uncertainty and are also significantly coarser with a sounding spacing of 25 to $50 \mathrm{~m}$.

The spatial extent of the surveys is variable. The two earliest surveys (1995 and 2004) covered an area several kilometres in length and width. The later 2009, 2013, 2014 and 2015 surveys followed the cable routes and covered an additional 200 by $200 \mathrm{~m}$ area centred on the wind farm foundation. Because the dune moved through this fixed survey area in later years (2013 onwards) the full extent of the dune was not captured by the surveys.

\subsection{Coupled hydrodynamic-sediment model}

The hydrodynamics and sediment transport on and around the dune were modelled using two modules from the open-source TELEMAC-MASCARET modelling system (www.opentelemac.org). In this system, the three-dimensional, time-varying flow field and suspended sediment concentrations are solved at short time intervals by the TELEMAC3D hydrodynamic module. The GAIA module (Audouin et al., 2019), coupled at the same time interval, uses this information from the hydrodynamic model, in addition to the settling velocities of the suspended sediment, to calculate the bed exchange fluxes, bedload transport and bathymetry variations. The updated bathymetry and bed sediment exchanges are then passed back to TELEMAC3D for updating the flow field and suspended concentrations during the next iteration. This full coupling at the time-step interval ensures accurate results and a mass conservative computation of the sediment transport and bed-level changes.

The model geometry comprised a rectangular domain centred around the barchan dune and rotated to be in line with the peak flow vectors. The model boundaries were positioned sufficiently far away from the dune so as to not adversely affect the hydrodynamics. For boundary conditions, the lateral boundaries of the domain were set as solid walls, whilst the tidal forcing was applied at either end using time series of water levels and discharges that were extracted from an existing large area model of the North Sea.

A $5.8 \mathrm{~m}$ diameter monopile was included in the model mesh as a circular island located approximately in the middle of the dune. The mesh resolution around the monopile was $0.5 \mathrm{~m}$. Away from the monopile, on top of the barchan dune, the resolution was $2 \mathrm{~m}$, and gradually coarsened away from the dune to a resolution of 25 $\mathrm{m}$. In the vertical axis, the model was discretised using 14 irregularly spaced sigma planes, with the finest spacing applied to the first three planes above the bed at heights of $1 \%, 2.5 \%$ and $5 \%$ of the total water depth, respectively. Above the dune, where the water was approximately $18 \mathrm{~m}$ deep, this equated to a nearbed resolution of approximately $0.2 \mathrm{~m}$. The remaining planes were all spaced through the water column to the surface at constant intervals of $10 \%$ of the total water depth. 
The mobile sediment of the dune was represented as a single sand fraction with a grain size of $0.5 \mathrm{~mm}$, on top of a non-erodible layer. The bedload transport and bed exchange fluxes were modelled in GAIA using the formulations of van Rijn (1993).

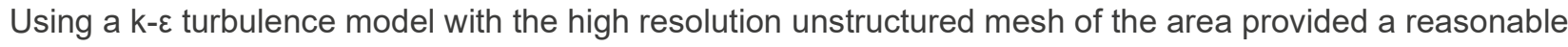
approximation of the eddy shedding and scour mechanisms behind the monopile. The turbulent kinetic energy (TKE) from the $k-\varepsilon$ turbulence model, extracted at the first plane above the bed, was used directly to calculate the scour inducing bed shear stress around the monopile. This was achieved by multiplying the TKE by a factor of 0.19 and dividing by the water density (Pope et al, 2006). Away from the monopile the bed shear stress was modelled using the log law formulation of Nikuradse, with the bed friction for form drag defined using a roughness length of $0.1 \mathrm{~m}$ across the whole domain.

\section{Results}

\subsection{Dune morphology and evolution}

\subsubsection{Observations made using bathymetry time-series}

Whilst barchan dunes are often found grouped with numerous other dunes (fields), the dune studied here (Figure 4a) had only two neighbouring dunes within the surveyed area, one located $1.8 \mathrm{~km}$ to the northnortheast (Figure $4 \mathrm{~b}$ ) and the second a further $1.4 \mathrm{~km}$ in the same direction (Figure 4c). In contrast to the study dune (Figure 4a), these two dunes have elongated western horns with a length 2 to 3 times wider than the eastern horn.

Initially, in 2004, the case study dune (Figure 4a) was weakly asymmetrical with the eastern horn being 1.1 times the width of the western horn. The dune had a width of approximately $370 \mathrm{~m}$ and a length of $190 \mathrm{~m}$. A peak in dune height of $6.9 \mathrm{~m}$ was observed in 2013. Using the 2009 survey (the highest resolution survey to cover the entire footprint of the dune) the total dune volume is estimated to have been $80,000 \mathrm{~m} 3$. The slip face of the dune had an average slope of $30^{\circ}$, close to that of the angle of repose $\left(\sim 32^{\circ}\right)$, and hence is consistent with an actively migrating bedform.

Superimposed atop the stoss slope of the dune were megaripples with heights of $0.1-0.3 \mathrm{~m}$ and wavelengths of $5-7 \mathrm{~m}$. These were visible in the latest three surveys (Figure 5, showing the 2015 bathymetry), though were likely still present in the earlier years but are not visible due to the lower resolution of those surveys.

The morphology of the barchan dune did not remain fixed in time. Each panel in Figure 6 shows a bathymetric survey from 1995 to 2015 . The black circle in panels $d$, e and f denotes the location of the monopile foundation. The monopile was installed in December 2010, after the 2009 survey (Figure 6c) and before the 2013 (Figure 6d) survey. Figure 7 shows the outline of the footprint of the dune identified from each repeat bathymetry survey. By tracking the location of the dune's brink, toe, western and eastern horns the migration rate and direction were found. The dune displayed a rate of migration towards the southwest $\left(205^{\circ} \mathrm{N}\right)$, ranging between 19 and $34 \mathrm{~m} / \mathrm{yr}$ and was on average $25 \mathrm{~m} / \mathrm{yr}$. 


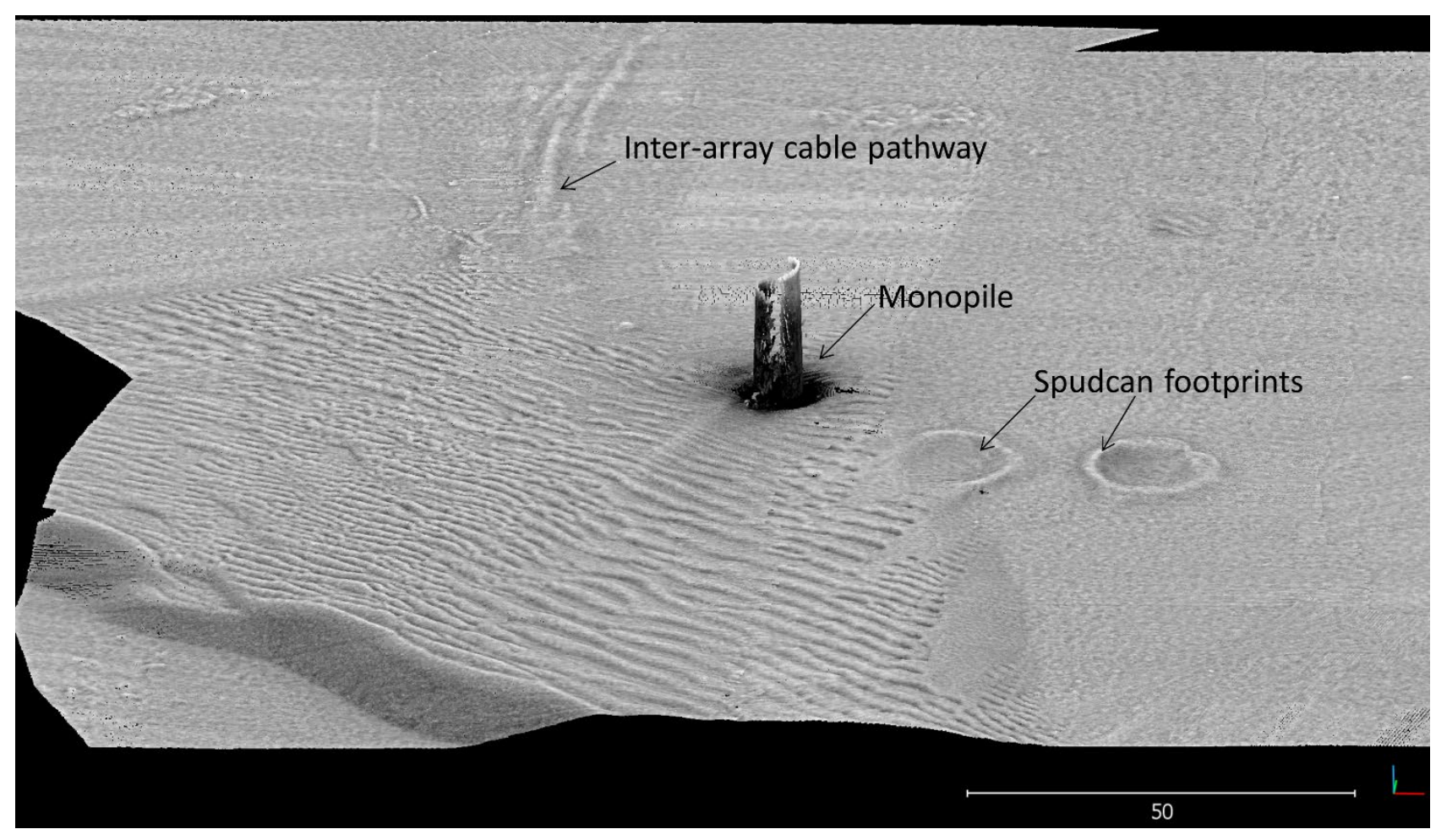

Figure 5. Annotated point cloud of the 2015 bathymetry survey with 'portion of visible sky' hillshade applied. The horizontal scale is in metres. 

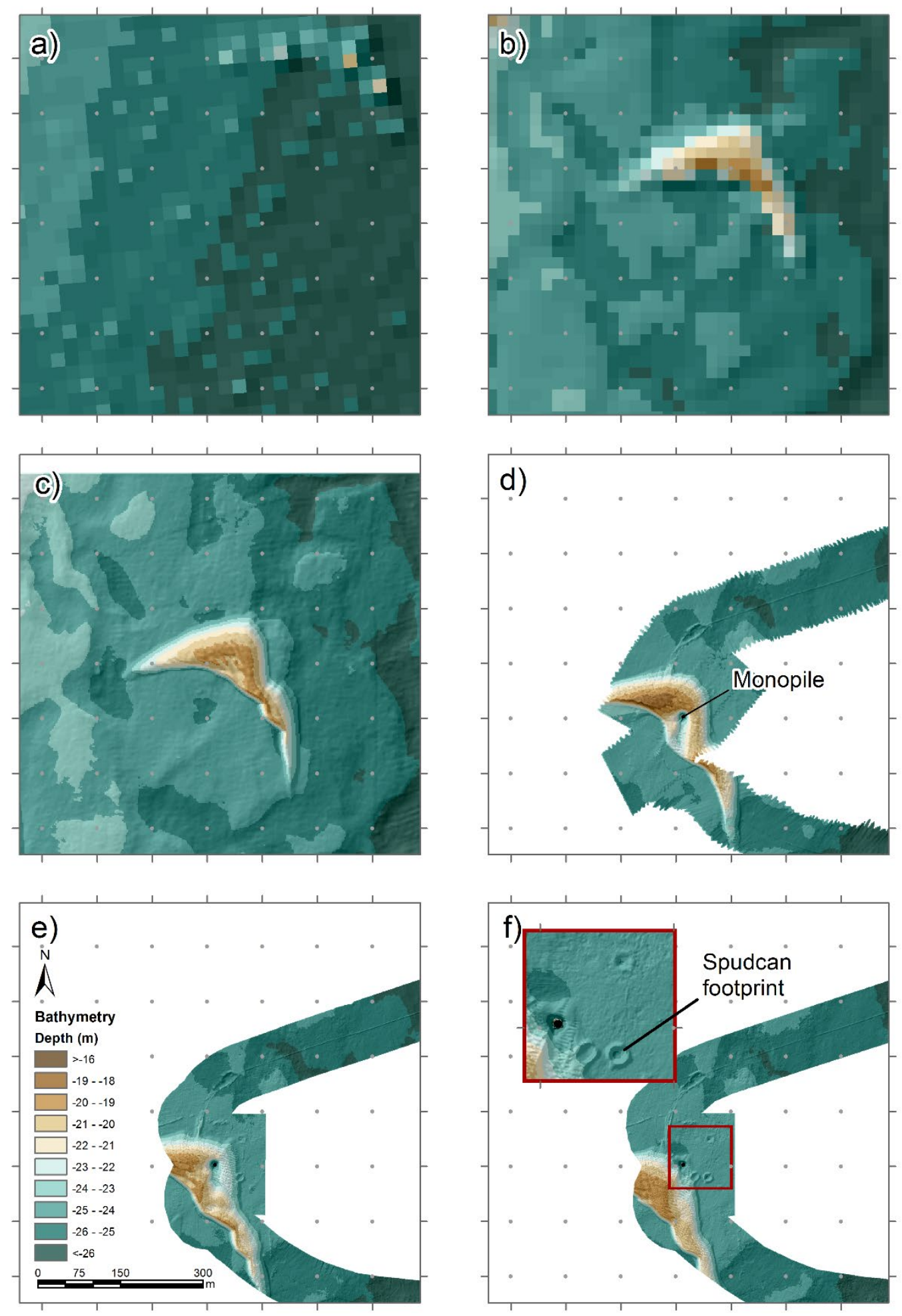

Figure 6. Panels showing the bathymetry from the a) 1995, b) 2004, c) 2009, d) 2013, e) 2014 and f) 2015 surveys. The frame of reference is kept the same for each panel. 


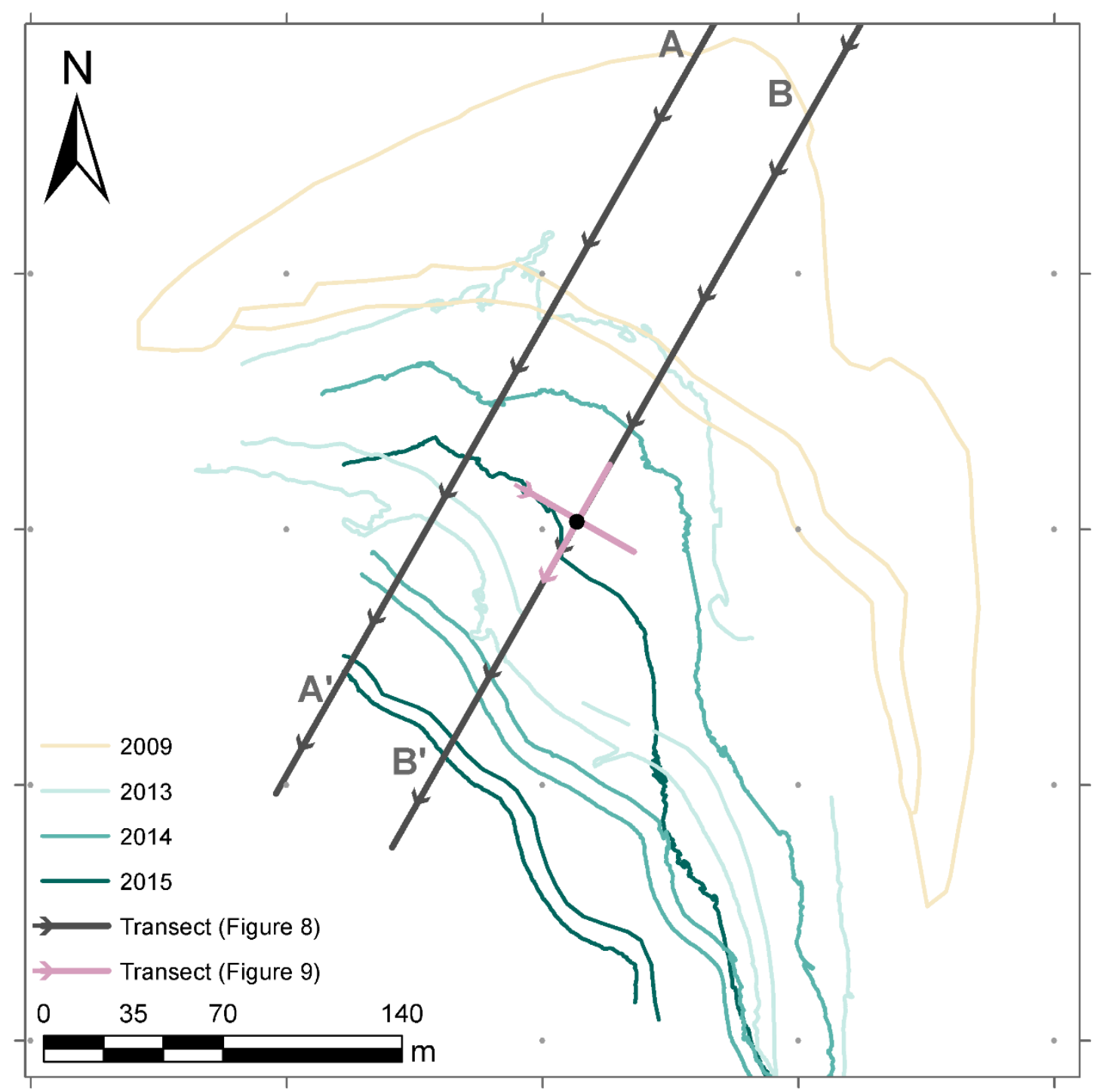

Figure 7. Outline of the barchan footprint for each survey. Transect lines used in Figure 8 are shown in grey, transect lines used in Figure 12 are shown in lilac.

The starting (2004) morphology (Figure 6b) was a fairly symmetrical, characteristic, barchan shape (though the survey resolution limits how well its form can be defined). By 2009 the eastern horn was longer than the western and the dune had a second, smaller, eastern toe. From 2009 to 2013 (during the phase when the monopile was installed) this secondary toe became much more pronounced, forming an almost separate barchan dune breaking away from the main dune.

Once the dune came into contact with the monopile, approximately one year after the installation of the monopile, we interpret that the slip face of the barchan dune became less crescentic and more sinusoidal as the flow-wake interaction locally impacted the morphology of the crest and brink of the dune. This is captured in the surveys of 2013 and 2014 (Figures 6d and e), with recovery to a more crescentic form once again by the time of the 2015 survey. During the period from 2013 to 2015 the slip face of the eastern half of the dune flattened out and the two barchan forms merged back into a single elongated barchan dune. 
The migration of the dune and changes in its morphology are clearly visible in the two transects taken through the latest four surveys (Figure 8a and b). Transect A (Figure 8a) is offset $25 \mathrm{~m}$ to the northwest of the dune's centreline, whilst Transect B (Figure 8b) is aligned with the monopile, $25 \mathrm{~m}$ to the southeast of the centreline. The dune morphology (length, height and slope) along the two transects prior to monopile installation, in 2009, was comparable. Following the installation of the monopile, by 2013 , the dune profile along Transect $A$ had narrowed and steepened, whilst along Transect $B$ the dune elongated by $10 \mathrm{~m}$. The dune profile along Transect $B$ was split with a gap formed by the local scouring processes at the base of the monopile (described in detail in Section 4.2). The half of the dune ahead of the monopile was approximately $2 \mathrm{~m}$ lower than the section behind and had a relatively flat top from where material had been removed in the wake of the monopile through scouring.

a)

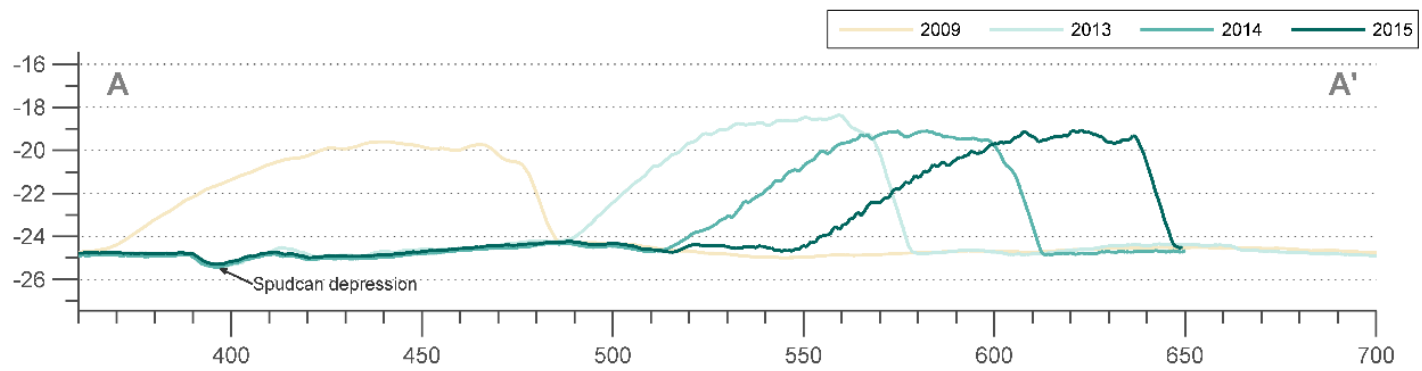

b)

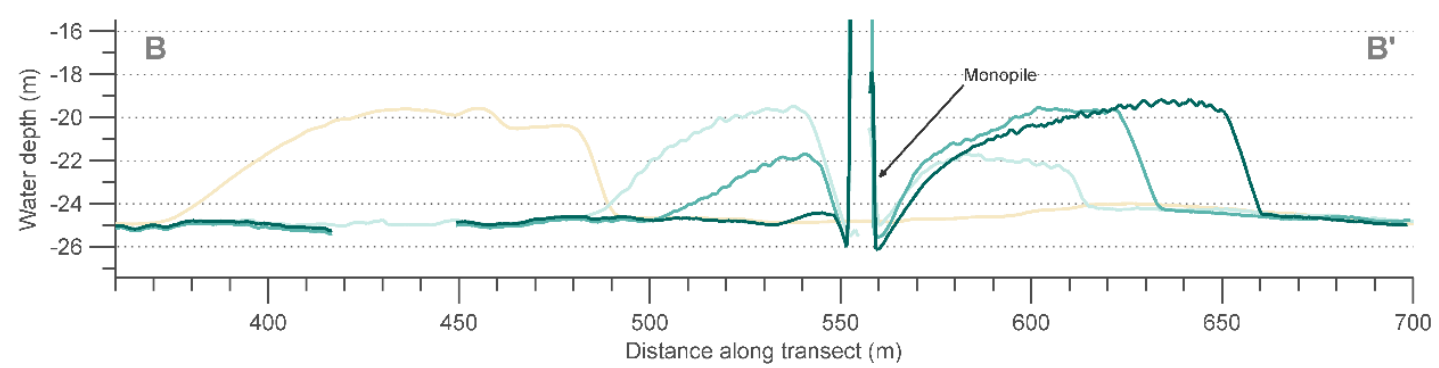

Figure 8. Transects through a) the dune, offset $25 \mathrm{~m}$ to the northwest of the centreline and b) the dune and monopile, offset $25 \mathrm{~m}$ to the southeast of the centreline, for the 2009 to 2015 surveys. Position of transects shown in Figure 7.

Between 2013 and 2014 the dune along Transect A regained some of its length and lowered in height. Transect $B$ regained much of its height in the wake of the monopile, as the transect no longer intersected the wake scour. Over this period the dune migrated relatively rapidly along Transect $A$ at a rate of 30 to $35 \mathrm{~m} / \mathrm{yr}$, whilst the dune at Transect $B$ migrated at a rate of just $20 \mathrm{~m} / \mathrm{yr}$.

The profile of the dune along Transect A remained similar between the 2014 and 2015 surveys; both the toe and the slip face migrated at a rate of $35 \mathrm{~m} / \mathrm{yr}$ over this period, preserving the height and length of the dune. The dune's length along Transect $B$ reduced by $10 \mathrm{~m}$ over this period, as the slip face migrated $5 \mathrm{~m} / \mathrm{yr}$ slower than the toe over this period. The maximum heights of the dune along Transect A and B in 2015 were within $0.1 \mathrm{~m}$ of one another and the lengths of the dune along the two profiles were within $1 \mathrm{~m}$ of one another, indicating that the dune shape had recovered from the modifications caused by the monopile.

To summarise, along the two transects, the pre monopile installation (2009) and final (2015) dune morphology (height, length and slope) are comparable. This indicates that the dune recovered rapidly from the modifications that took place when the crest was in line with the monopile. 


\subsubsection{Observations made using coupled hydrodynamic-sediment model}

Figure 9 shows the bed shear stress over the dune for a single point in time (during the peak flood of a spring tide). The darker areas indicate where the shear stress is higher than the ambient level (e.g. atop the brink) and lighter areas indicate where the shear stress is lower (e.g. in the recirculation zone of the dune). The sediment in those areas experiencing elevated bed shear stresses are eroded and transported in the direction of the current (the pink arrows). On the brink, the shear stresses are remarkably high; they are sufficient to move gravels, let alone the sand of the dune. Downstream, where the bed shear stress then decreases, sediment particles taken into the recirculation zone are deposited.

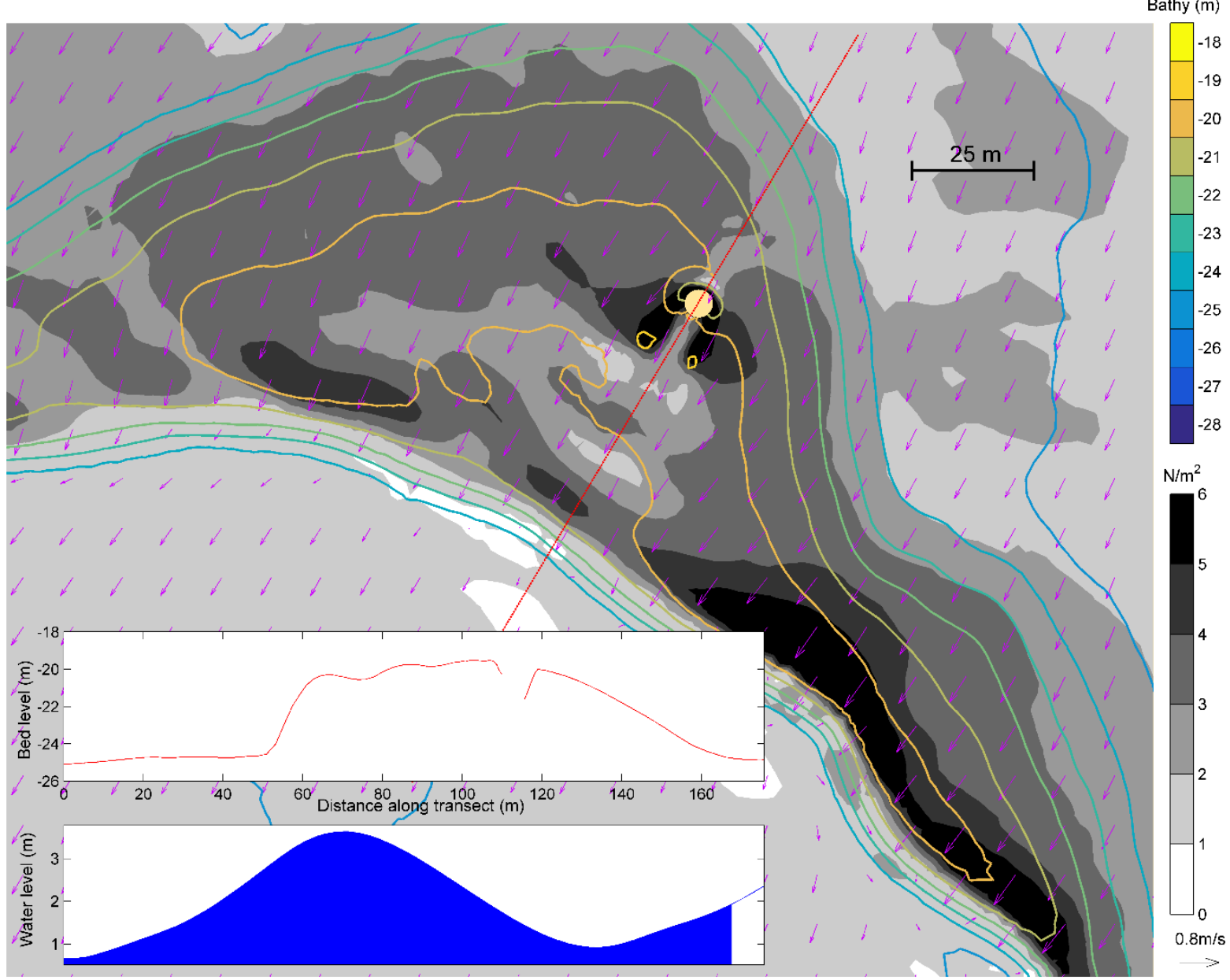

Figure 9. Numerically modelled near-bed shear stress (greyscale) during peak flood phase on a spring tide (water level in metres shown on lower inset panel). Bathymetry depth contours are shown at $1 \mathrm{~m}$ intervals. A transect is taken through the bed-level with the profile (top inset panel, both axes in metres) showing the formation of scour atop the dune. 
Over the period of the model simulation, a few tidal cycles, the material was eroded from the brink and deposited further down the slip face (Figure 10). This process is more apparent during the spring phase of the tide (Figure 11), but is still ongoing during the neap phase (Figure 10). During the spring flood tide, because of the high shear stress, the crest of the dune lowered by up to $0.3 \mathrm{~m}$, but returned to the original height during the ebb tides. Since the model was only run for a limited set of tidal cycles, elongation of the dune in the wake of the monopile was not apparent, but increased deposition was observed in the area immediately behind the monopile, which would have provided material for elongation of the dune when the monopile was closer to the slip face.

\subsection{Scour evolution}

\subsubsection{Observations made using bathymetry time-series}

By 2013 , three years after the installation of the monopile, a circular local scour pit had cut into the dune at the base of the structure. The local scour was relatively symmetrical, with an extent from the monopile wall to scour edge of 15 to $20 \mathrm{~m}$ (Figure 12). The total width of the scour hole (from edge to edge) was about $40 \mathrm{~m}$ (Figure $12 \mathrm{~b}$ ), about $11 \%$ of the barchan width of $370 \mathrm{~m}$. For comparison, the ratio of the monopile diameter to barchan width was only $1.6 \%$.

Extensive wake scouring was also observed. The wake scour extended in two lobes: one to the southsouthwest and the other to the west-southwest. The more southerly of the two wakes was better defined. The two wakes were separated by a small mound of material, aligned directly downstream $\left(205^{\circ} \mathrm{N}\right)$ of the monopile.
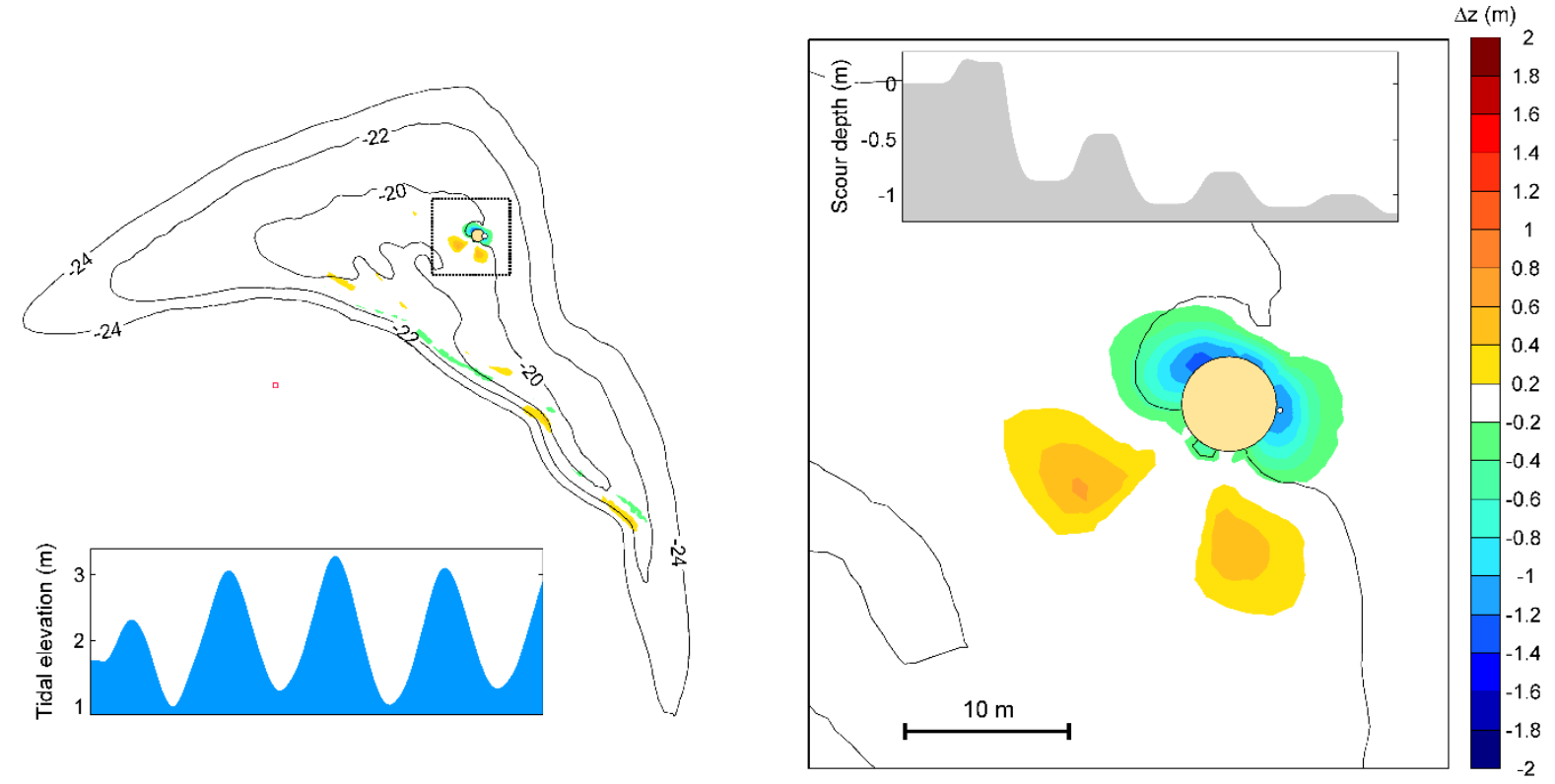

Figure 10. Numerically modelled bed-level change $\Delta z$ (red indicates net deposition as positive and blue indicates net erosion as negative) after a series of five ebb-flood tides on the neap phase of the tide (lower left inset panel with water level in metres). In the enlarged panel the development of the scour in metres is shown for a point taken on the east of the monopile. 

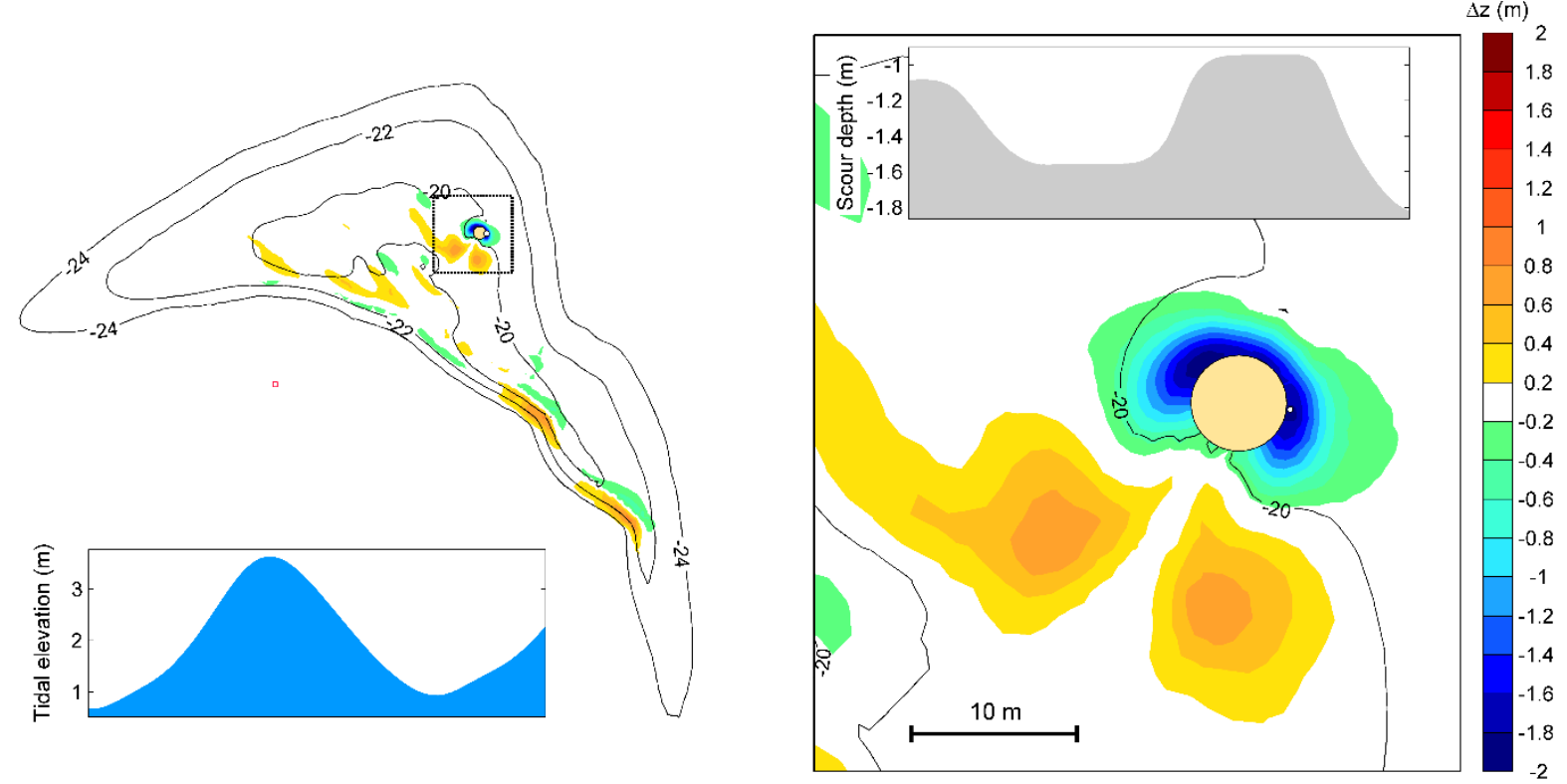

Figure 11. As Figure 10, except showing spring tides.

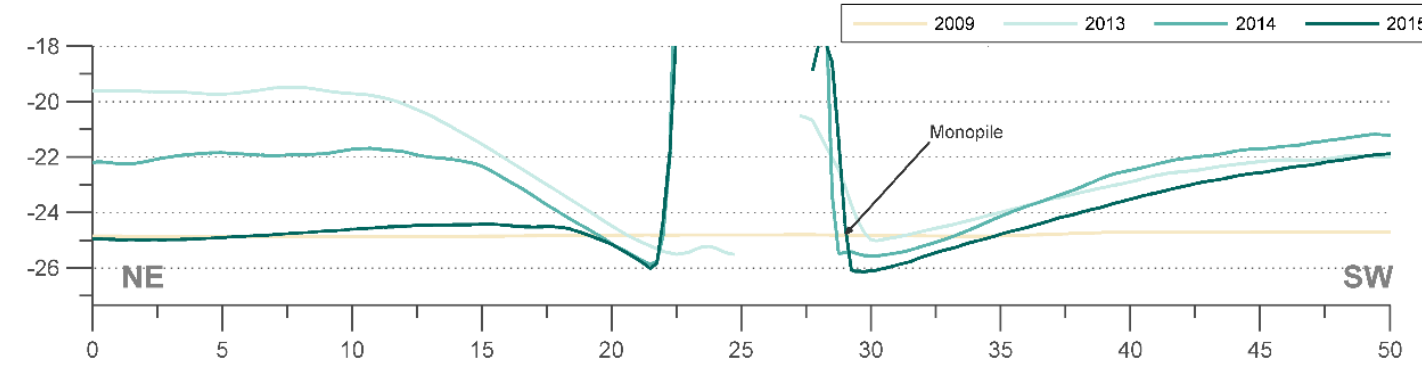

b)

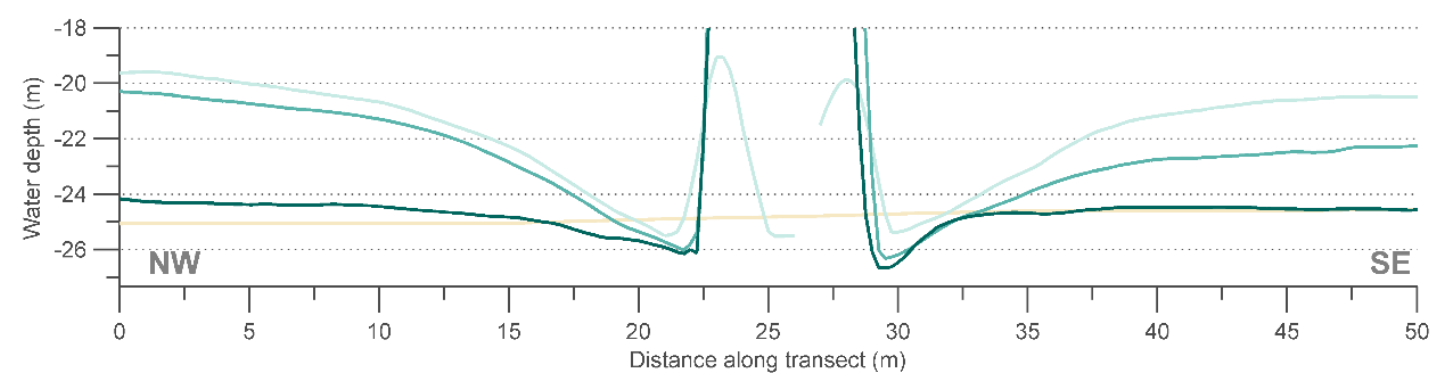

Figure 12. Transects showing the development of scour along the a) flow-aligned axis and the b) flowperpendicular axis. Position of transects shown in Figure 7. 
Commonly when measuring scour, the level at the base of a scour pit is compared with the ambient seabed level to give a scour depth. However, at the study location the bed-level locally increased and then subsequently decreased as the dune passed the monopile. Therefore, care must be taken when choosing the level with which the base of the scour pit is compared. If the scour level is compared with the bed-level at the edge of the scour pit (which was aligned with the crest position in 2013) then we see a much larger scour depth, reaching a maximum of $6.8 \mathrm{~m}$ in 2013 (Table 1, 6th column). The maximum scour depth relative to the ambient level (which can be inferred from the 2009 transect in Figure 12) provides an estimate of the depth of the scouring into the underlying seafloor (Table 1, 5th column). Scouring into the seafloor underlying the dune progressed year-on-year. Since the thickness of the surficial sand layer at this location is only a few 10 's of centimetres at most, this scour is likely to have cut into the clay layers below.

Table 1: Maximum scour depth at the base of the monopile for the three bathymetry surveys following the installation of the monopile. Scour depths are provided relative to the ambient seabed level (into veneer and clay), as well as relative to the height of the edge of the scour pit (into barchan and underlying veneer and clay)

\begin{tabular}{|l|l|l|l|l|l|}
\hline Year & $\begin{array}{l}\text { Ambient } \\
\text { seabed level } \\
\text { (mLAT) }\end{array}$ & $\begin{array}{l}\text { Bed-level at } \\
\text { edge of scour } \\
\text { pit (mLAT) }\end{array}$ & $\begin{array}{l}\text { Deepest scour } \\
\text { pit level } \\
(\mathbf{m L A T})\end{array}$ & $\begin{array}{l}\text { Maximum scour } \\
\text { depth into } \\
\text { veneer and clay } \\
(\mathbf{m})\end{array}$ & $\begin{array}{l}\text { Maximum scour } \\
\text { depth into barchan } \\
\text { and underlying } \\
\text { veneer and clay }(\mathrm{m})\end{array}$ \\
\hline $\mathbf{2 0 1 3}$ & -24.7 & -19.5 & -26.3 & 1.6 & 6.8 \\
\hline $\mathbf{2 0 1 4}$ & -24.7 & -21.7 & -26.5 & 1.8 & 4.8 \\
\hline $\mathbf{2 0 1 5}$ & -24.7 & -24.4 & -27.0 & 2.3 & 2.6 \\
\hline
\end{tabular}

\subsubsection{Observations made using coupled hydrodynamic-sediment model}

In the coupled hydrodynamic-sediment model we observe elevated TKE levels at the monopile and consequently, higher values of bed shear stress (Figure 9). The result of this is that the scour development in the model happened quickly compared to the rate of movement of the dune.

Over the course of two days, during a set of neap tides, the modelled scour developed to a depth of $1.2 \mathrm{~m}$ below the initial bed-level and extended $5 \mathrm{~m}$ from the pile wall (Figure 10). By the end of this neap tidal cycle, the modelled scour rate had diminished. The overall rate of scour was slowed by the reversing tidal flows due to backfilling. Most of the scour occurred during the faster-flowing flood phase of the tide, with scour developing mainly on the northeast side of the monopile. During the following ebb tide, the scour hole tended to partially fill back in on the northeast side of the monopile and scour developed more on the southeast side. This cycle then continued on the following tide, with a gradual increase in scour depth over time.

For the modelled spring tides, which was initialised with the bathymetry at the end of the neap tide simulation, the higher flows and bed shear stresses led to a further increase in the scour hole depth to $1.8 \mathrm{~m}$ (i.e. an increase of $0.6 \mathrm{~m}$ ) and extension of the radius of pit by $2 \mathrm{~m}$, over a period of one full tide (Figure 11). The model predicted the direction of the sour holes reasonably well, but did not reproduce the extent of the lobes, which in Figure 6e extend all the way to the slip face. 


\section{Discussion}

\subsection{Impact of the monopile on the barchan dune}

The survey taken in 2013 (Figure 6d), following the installation of the monopile, shows the length of the dune increasing in the wake of the monopile causing the slip face to become sinusoidal in profile. This observation seems to indicate that, subsequent to the installation of the monopile, there was accelerated transport of sediment from the toe of the dune, past the monopile, which was then deposited a short distance downstream in the wake of the monopile.

The coupled hydrodynamic-sediment model TELEMAC3D-GAIA provided some further insight in the dynamics of the dune. If the results of the model are translated to the time when the dune first encountered the monopile, the pattern of erosion (at the base of the monopile) and deposition (downstream in the wake of the pile) shown in Figure 10 and Figure 11, can be used explain the stretching of the dune seen in Figure 6d.

The field and numerical observations are in support of those made by Chiew (1984) and Hong et al. (2017) where, in their physical models, the mid-section of an approaching dune was drawn into the scour hole of a monopile. The sediment in the mid-section travelled at a faster rate causing elongation, whilst the rest of the dune lagged behind. In their models it was shown that the dune crest caught up and straightened out approximately half a dune's length downstream of the monopile. In the case of the barchan dune we would expect this to occur at a distance of 75 to $100 \mathrm{~m}$ downstream of the monopile. This corresponds well with the reduced impact of the scour wake process, which led to a straightening out of the dune's slip-face by 2014 occurring at a distance of approximately $100 \mathrm{~m}$ downstream (Figure 6e).

Whilst it is straightforward to attribute the changes due to the installation of the monopile, some subtle changes were noted prior to the installation of the monopile (Figure 6c). Therefore, there is some natural variability in the morphology of the dune. We see that the two dunes to the north (Figure 4b and 4c) are also elongated, suggesting that there are natural causes for this variability. Thus, at least partially, the elongation at the case study dune must have been triggered by natural variability.

Studies have shown that elongation and the separation of barchan dunes may be caused by changes in the topography, sediment availability and/or hydrodynamics (Lv et al., 2016). The lack of any underlying topography and the absence of any sources of additional material to the dune make it likely that the cause of any variability in morphology is driven by changes in the local hydrodynamics. Ma et al. (2014) postulated that the trigger mechanism for the formation of smaller dunes (when there was no clear additional source of material) is that during periods of stronger currents (in their case, during typhoons or tropical hurricanes) the host barchan cannot supply enough sand to maintain its horns. Instead the horns move faster, due to their smaller scale, and break away from the host dune. This seems the most likely mechanism by which the eastern horn began to break away. During the winter months wave heights can be in excess of $4 \mathrm{~m}$ (Figures 2 and 3); for a water depth of approximately $25 \mathrm{~m}$ these waves will be felt at the seabed, in the form of increased total shear stress. Therefore, the wave action may accelerate the transportation of material down the dune's horn, potentially initiating the breakaway of a smaller dune.

Whilst the modification in the dune plan shape asymmetry cannot be fully attributed to the deviation and acceleration of flow around the monopile, there are some processes directly attributable to this flow modification, such as the removal of material at the base and in the wake of the monopile. In 2014 the total volume of the material scoured locally and in the wake of the monopile was approximately $6,000 \mathrm{~m} 3$. Given an estimated dune volume of $80,000 \mathrm{~m} 3$ a total volume of $8 \%$ of the dune material was scoured. Potentially 
some of this material may have been lost entirely from the dune through the scouring process. A small wedge shape zone of deposition is visible on the seafloor downstream (i.e. south-southwest) of the slip face in the 2013 (Figure 6d) and 2014 (Figure 6e and Figure 13) surveys. This wedge of material is no longer visible by the time of the 2015 survey. It is feasible that this material (which is clearly mobile given the presence of small bedforms across the deposit) was transported further away from the dune and may, as a result, have been lost from the dune's total volume. Unfortunately, the post scouring volume of the whole dune cannot be determined using the bathymetry data (the later surveys do not cover the whole dune) and so any loss of material from the dune cannot be quantified.

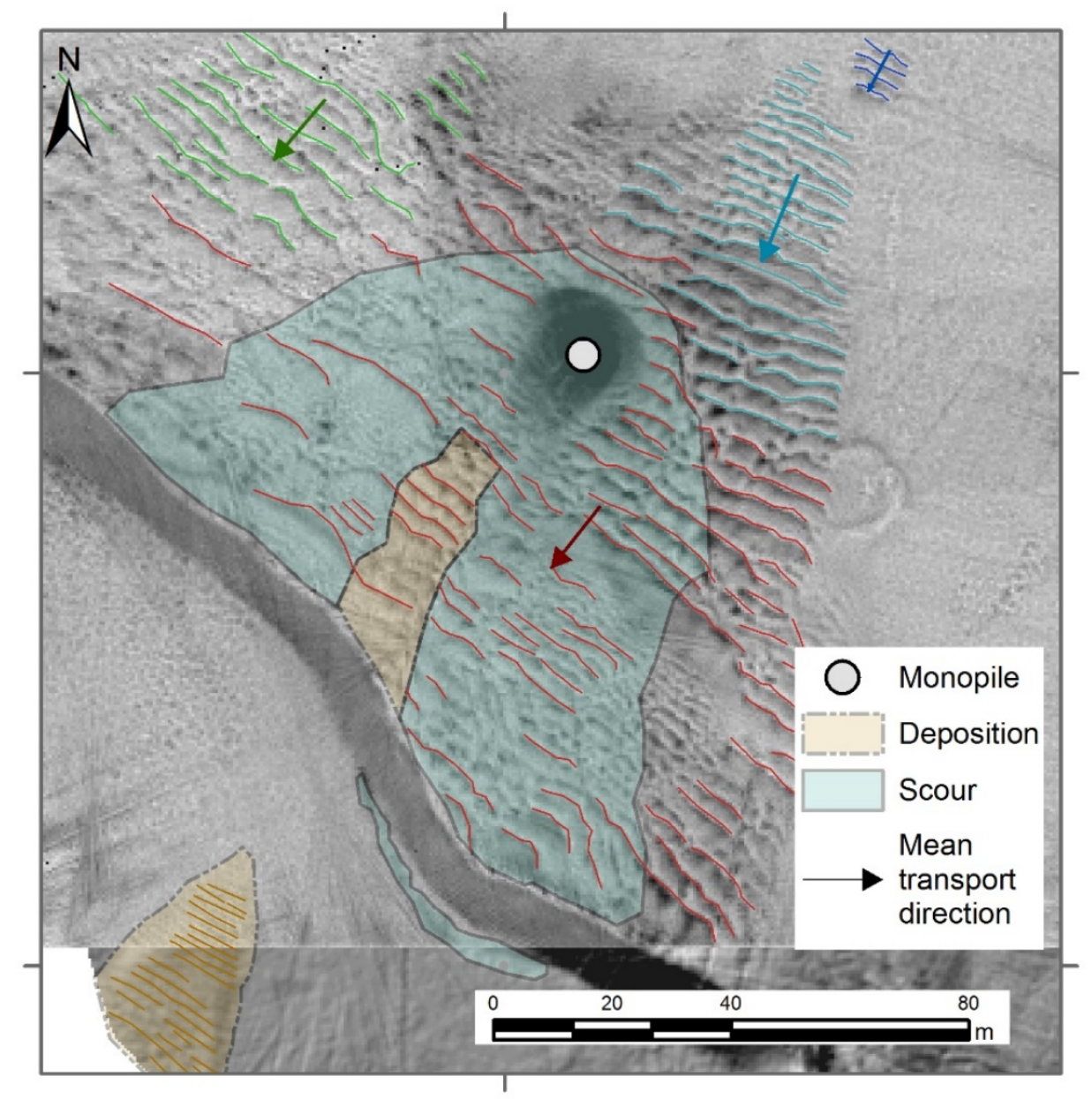

Figure 13. Bedform crests on the east of the toe (light blue), west of the toe (green), main body (red) and within the spudcan footprint (blue), identified in the 2014 bathymetry.

In Figure 13, the 2014 positions of the crests of the megaripples atop the dune have been highlighted. Towards the toe, on either side of the main body, the bedform crests (highlighted in green and light blue) are orientated more towards the horns (on average by $4^{\circ}$ on the western side and $16^{\circ}$ on the eastern) than the crests atop the main body (highlighted in red), which are orientated in the direction of travel of the dune. This is in good agreement with the near-bed flow fields that have been mapped out using numerical modelling (e.g. in our own model, Figure 9 and Omidyeganeh et al., 2013). The flow at the toe of the dune diverges 
towards the horns, whilst further up the stoss slope the flow becomes more aligned with the ambient transport direction.

By mapping the crests of the bedforms observed upon the barchan dune it is shown that the presence of the monopile has no observable impact on the alignment of the bedforms; the bedforms in proximity to the monopile remain aligned with the slip face and overall transport direction of the dune. Interestingly, the bedforms within the wake of the monopile are not aligned with the direction of the wake scours (towards the west-southwest and the south-southwest). This highlights a potential disconnect between the bedload transport that drives the formation of the bedforms and the flow in the wake of the monopile leading to scour.

The observed barchan dune is moving at a relatively high speed of about $25 \mathrm{~m} / \mathrm{yr}$ over a coarser substrate. Therefore, it does not create any locations that have reduced shear stresses and potential for fine sediment deposition over longer periods that might promote the development of habitats for macrofauna, as seen in the lee of more stable large dunes (Van Lancker et al., 2013).

To summarise, as shown in the studies of Chiew (1984) and Hong et al. (2017), the dune was stretched by the accelerated flow field around the monopile. Also, in agreement with their studies, this effect was temporary and so there were only limited long lasting impacts on the dune's morphology, which recovered once the dune had migrated away from the monopile.

\subsection{Impact of dune on processes at the base of the monopile}

At the time of foundation installation (December 2010) the slip-face of the barchan dune will have been approximately $30 \mathrm{~m}$ to the northeast, and (even considering the observed upper bound migration rate) the foundation will have been ahead of the dune's position (Figure 14). Using the empirical model of Sumer et al. (1992) scouring will have penetrated into the gravelly sandy veneer of the seafloor less than 24 hours after installation. Scouring will have continued into the clay layer beneath, but at a considerably slower rate, as evidenced by the scour continuing to erode into the clay layers between the 2013 and 2015 surveys at neighbouring foundations. 


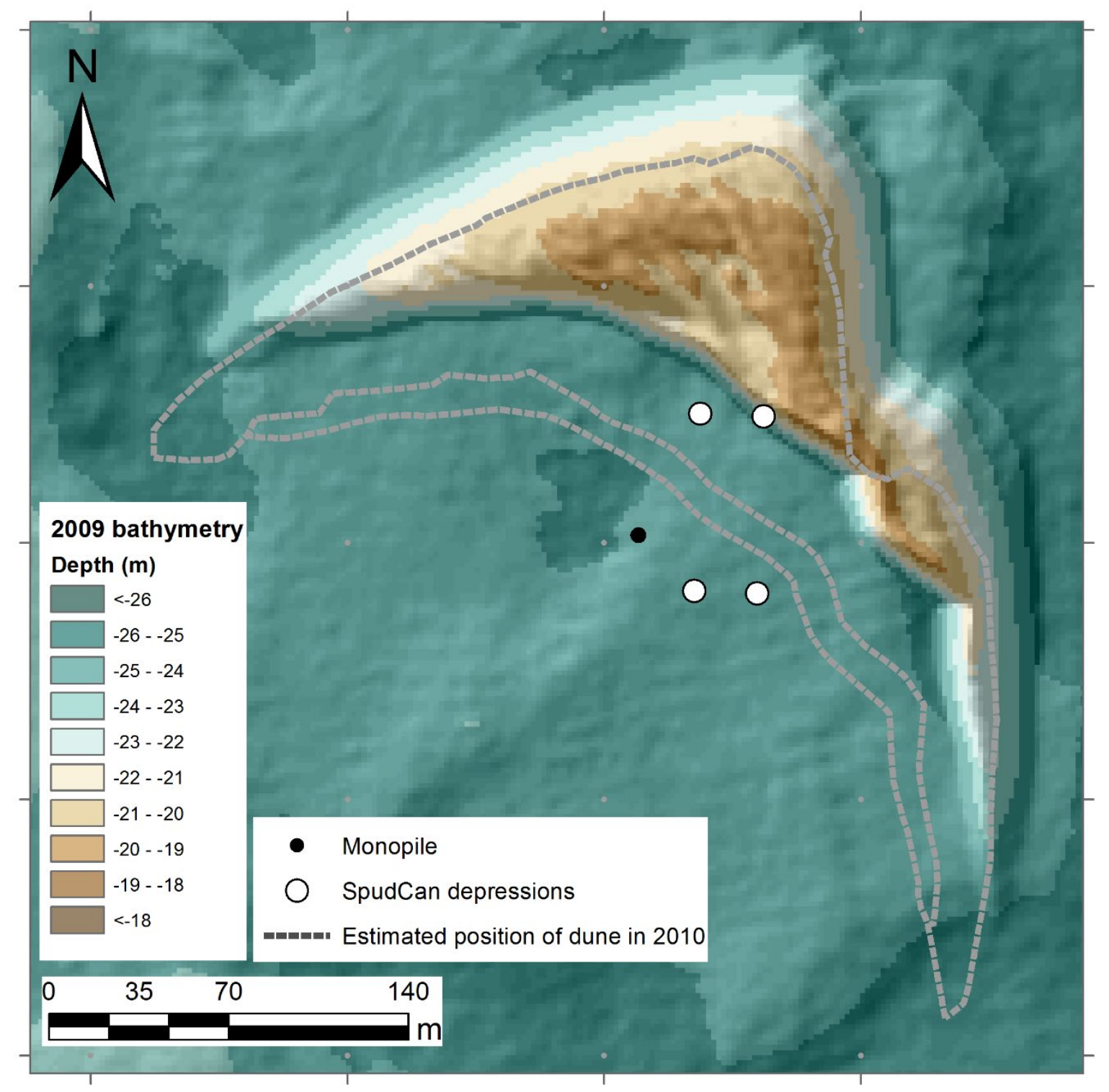

Figure 14. Estimated position of the barchan dune at the time of monopile installation (2010), with location of monopile and jack-up footprint depressions shown. 
The maximum scour depth relative to the edge of the scour pit (i.e. including the depth scoured through the dune itself) was $6.8 \mathrm{~m}$ in 2013, equivalent to 1.2 pile diameters. This is comparable with empirical observations, which suggest a scour depth approximately 1.3 times the monopile diameter in sand (Sumer et al., 1992), which would give a depth of approximately $7.5 \mathrm{~m}$. This suggests that the scour depth through the barchan dune is similar to scouring in a flat bed of sandy sediments (Harris and Whitehouse, 2015). It is, however, apparent that, in the current situation, the seabed underlying the barchan is providing some element of geological control to the scour depth formation. This observation highlights the difference in time scales of these two sedimentary processes; the scouring will have taken place over a period of a few weeks, whilst the dune has taken several years to migrate past the foundation, giving ample time for the scouring to take place to near-equilibrium within the thickness of the granular material in the dune.

Much like scour on a flat area of seabed, the scouring atop the dune body presented two individual wakes separated by a wedge of deposition (Figure 13). The flow model confirmed the direction of the wake scour lobes visible in the surveyed bathymetry. In the model, the scoured sediment tended to be deposited immediately downstream of the monopile, forming mounds on the southwest side due to the stronger flood tide flows. The bedload transport and erosion flux of the bed material caused by the TKE around the monopile was considerably higher than away from the monopile. The relatively short duration of the simulation meant that more sand was scoured from around the monopile to the south-southwest and the west-southwest than could be moved away from those areas. If the simulation were continued, the scour hole would stabilise, allowing the flows to slowly remove the initial sediment deposits. Given enough time the scour lobes would extend further south-southwest and west-southwest.

In the survey data the western wake scour was less prominent than the more southerly scour. It is thought that this may be due to the position of the two wakes relative to the main body of the dune. The western wake was further up the slope and so likely received material from upstream due to transport over the dune. This is suggested by the zone of bed changes in that area in the model (Figure 11). The material will have been transported down the slope and into the scour pit, slightly infilling it, whereas the more southerly wake was separated from the main body of the dune in deeper water with less thickness of sediment and will have received less infill as a result.

Relative to the ambient seabed the scour depth progressed at a rate comparable to neighbouring monopiles, giving a maximum scour depth of $2.3 \mathrm{~m}$ in 2015 in the seabed veneer and clay (Table 1, Column 5). This results in a ratio of scour depth to pile diameter of about 0.4 , which is comparable to other sites in nongranular soils (Harris and Whitehouse, 2017). Even from the first survey time-step after the installation of the monopile (2013) the level at the base of the scour pit was deeper than the ambient bed-level, i.e. it had scoured the full depth of the barchan dune and then maintained scour into the underlying seabed. For the four nearest monopile foundations (within a $1 \mathrm{~km}$ radius), the maximum local scour depths were, on average, $1.5 \mathrm{~m}$ in 2013, $1.7 \mathrm{~m}$ in 2014 and $2.1 \mathrm{~m}$ in 2015. The scour depths observed at the dune study site are all within $0.2 \mathrm{~m}$ of the average observed nearby scour depths. This suggests that the presence of the barchan dune had minimal impact on the progress of the scour into the underlying seafloor and that the maximum scour depth was limited by the rate at which the scouring can occur, which was slowed by the presence of stiff clays found at a depth of 0.5 to $1 \mathrm{~m}$ below the sediment veneers. In the study of Hong et al (2017) it was observed that compared with a flat seabed the local scour depth was increased when the trough of a dune was coincident with the scour hole. Potentially the absence of a bedform trough (found with linear bedforms but not barchan dunes) meant that the scour depth did not form more deeply into the underlying seabed.

We are able further demonstrate that presence of the barchan dune had minimal impact on the overall progress of the scour by using measurements of natural frequency of the wind turbine assembly. The natural frequency was monitored using accelerometers in the nacelle of the wind turbine generator. This time series 
gives an indication of the stiffness of the monopile foundation, which is controlled by the properties of the wind turbine assembly, the soil properties, water depth, and the lateral resistance and displacement of the foundation in the soil. As soil from around the monopile is removed through the process of scouring the monopile becomes less stiff and the natural frequency will reduce (Mayall et al., 2019). Measurements of natural frequency were taken every 10 minutes and were then averaged on a monthly basis. Overall the natural frequency reduced over the monitoring period (February 2012 to February 2019). This reduction was in line with the general trends observed at neighbouring foundations, indicating that the year-on-year scouring into the underlying seabed was largely unaffected by the presence of the barchan dune. However, there was a temporary increase in natural frequency towards the beginning of the morphological time series (Figure 6d); the natural frequency was temporarily elevated from early 2013 through to October 2014, with a peak in July 2013, which we expected, on the basis of our migration estimates, to have the greatest thickness of additional overburden from the barchan. This peak, although noticeable, was only half the amplitude of the overall reduction in natural frequency over the entire time series. When compared with those foundations where scour protection (rock dump) was installed the increase in frequency afforded by the overburden of the barchan dune was less than two and a half times that of the increase following the installation of the scour protection. Although some stiffening is provided by the overburden of the barchan dune, the near instantaneous scouring into the dune prevented the dune from providing as much support as a non-scourable material, e.g. from scour protection rocks.

\subsection{Spudcan depressions}

The monopile was installed using a jack-up rig, with four feet (spudcans), positioned to the east of the monopile location. Since no bathymetric survey was taken at the time of monopile installation (2010), the closest in time was the 2009 survey. From this time-step we project forward (along a bearing of $205^{\circ} \mathrm{N}$ ) the outline of the dune by $25 \mathrm{~m} / \mathrm{yr}$ (the average annual migration rate from 2009 to 2013) to give an estimated position of the dune at the time of monopile installation (Figure 14). This estimate does not account for asymmetry in migration across the dune. However, since the time gap is small the estimated outline is a reasonable approximation.

At the time of installation of the monopile, the northernmost two legs of the jack-up rig would have penetrated into the dune, with a depth of sand beneath them of approximately 4.3 and $4.9 \mathrm{~m}$ for the west and east footprints, respectively, based on the estimated position in Figure 14. The southern two legs were planted to the south of the dune and so the jack-up legs will have penetrated through the veneer and into the underlying clay. This arrangement is confirmed by the jack-up vessel's log, which details the penetration of the jack-up legs. The two northern legs penetrated much less deeply due to the higher bearing capacity of the dune's sand compared with the soft clay seabed.

Virtually no impression of the north-western footprint can be seen on the seafloor after the dune has passed and the north-eastern footprint is relatively poorly defined (Figure 6f). Given the presence of all four footprints at neighbouring foundations, the lack of a north-western footprint at the case study foundation is further evidence of the dune's position during the time of monopile installation.

Remarkably the southern two spudcan depressions and, to a lesser extent, the north-eastern depression were still visible even after the dune had passed over them. The spudcan footprint consists of a 0.2 to $0.5 \mathrm{~m}$ deep circular depression with a $0.8 \mathrm{~m}$ high ring formed from the displaced material. Locally, at foundations that have not been disturbed by bedforms, the depth of the spudcan footprints range between 0.5 and $1.7 \mathrm{~m}$. This suggests that only a small volume of sand from the passage of the barchan has remained in the base of the depressions. Therefore, there has been limited or no long-term infilling of the spudcan footprints after the 
barchan dune has passed through. Bedforms, with heights of approximately $0.2 \mathrm{~m}$, are visible within the spudcan footprint (Figure 13, blue crests) suggesting that flow is not fully detached by the ridge of the footprint and can mobilise sediment within the footprint.

In 2013 the south-western spudcan depression would have had over $4 \mathrm{~m}$ of sand overlying it. The reappearance of a spudcan footprint in the wake of the barchan indicates that the dune does not exchange material with the ridge formed by material that has been displaced by the jack-up footing. This indicates that the displaced material is distinct to that of the material that comprises the barchan dune. It is hypothesised that, given its mobility, the barchan comprises sand whilst the ridge of material surrounding the spudcan footprints comprises of less mobile, potentially cohesive, sediment (clays).

These findings have implications for the use of spudcan footprints as indicators of how morphologically active a site is. In industry, the presence of spudcan footprints with clear outlines is used as an indication that a particular site is morphologically inactive. However, as it is shown here, the edges can remain clear even after being buried (and subsequently uncovered) by more than $4 \mathrm{~m}$ of sand. This suggests that the clarity of the footprint edges is not always a good indicator of the level of sedimentary activity at a given site.

\section{Conclusion}

In this paper, six repeat bathymetric surveys have been used to track and describe a singular barchan dune as it passes a wind farm monopile foundation where the dune height is of the same order as the monopile diameter $(5.8 \mathrm{~m})$. The impacts on both the barchan dune itself and the scour at the base of the monopile have been documented. The study highlights the importance of the relative length and timescales of the dune and of the monopile.

Even before the installation of the monopile the morphology of the barchan dune was irregular, the eastern horn elongated and a second toe had developed. Following the installation of the monopile the mid-section of the dune stretched out in the wake of the structure, causing the slip-face to become more sinusoidal in profile. In subsequent survey time-steps, the barchan dune gradually reformed into a singular feature. After the slip face of the dune had passed the monopile, the dune face flattened, with the western horn lagging behind the central body. The presence of the monopile had no visible impact on the pattern of bedform crests atop the barchan dune. The volume of material displaced in the wake of the dune amounted to $8 \%$ of the total dune volume. Whilst the monopile appeared to have an impact on the dune's morphology, this was temporary and recovery was rapid (within a couple of years).

Scouring at the base of the monopile progressed unhindered through the full depth of the barchan dune and into the underlying seafloor. This is because the time scale at which scouring occurs is significantly faster than the rate at which the dune migrates, allowing the process of scour to occur through the full thickness of the dune. Numerical modelling confirmed that the dynamics of the scour development happen at a far shorter time scale that those of the dune migration. The scour developed over a few tides, while in the same period the overall changes is the dune shape were limited to a lowering of the crest during the flood tide, followed by rebuilding during the ebb tide. Only a very small amount of sediment avalanched down the slip face.

The scour depth relative to the ambient bed-level was comparable with that observed around neighbouring monopile foundations. This indicates that the presence of the barchan had a limited impact on the scouring into the seabed. 
The dynamic response of the monopile, which is dominated by the first mode of the natural frequency of the wind turbine and foundation assembly, plays a key role in the fatigue life of the foundation. We observed, from the natural frequency of the monopile, that the overburden of the barchan dune temporarily stiffened the foundation, but that this was less than the stiffening effect afforded by the installation of rock protection at other foundations. In agreement with our starting hypothesis, the dune's presence did not alter the stability, and consequently the operational performance, of the wind turbine.

\section{Acknowlegments}

We are grateful to the Client who provided permission to present their data and HR Wallingford for their research funding.

Contains public sector information, licensed under the Open Government Licence v3.0, from the Maritime and Coastguard Agency. Contains information provided by Cefas and funded by Environment Agency, licensed under the Cefas WaveNet Non-Commercial Licence v1.0.

\section{Data availability statement}

Research data are not shared.

\section{References}

Audouin, Y., Benson, T., Delinares, M., Fontaine, J., Glander, B., Huybrechts, N., Kopmann, R., Leroy, A., Pavan, S., Pham, C.T., Taccone, F., Tassi, P., \& Walther, R. (2019). Introducing GAIA, the brand new sediment transport module of the TELEMAC-MASCARET System. TELEMAC User Club 2019, Toulouse.

Berné, S., Allen, G., Auffert, J.-P., Chamley, H., Durand, J., \& Weber, O., (1989). Essai de synthèse sur les dunes hydrauliques géantes tidales actuelles. Bulletin de La Société Géologique de France 6, pp. 11451160 .

Bristow, N. R., Blois, G., Best, J. L., \& Christensen, K. T. (2019). Spatial scales of turbulent flow structures associated with interacting barchan dunes. Journal of Geophysical Research: Earth Surface, 124, pp. 11751200. https://doi.org/10.1029/2018JF004981

Chiew, Y. M. (1984). Local scour at bridge piers. University of Auckland.

Crown Estate (2019). Offshore wind operational report: January - December 2018.

Ernstsen, V. B., Noormets, R., Winter, C., Hebbeln, D., Bartholomä, A., Flemming, B. W., \& Bartholdy, J. (2005). Development of subaqueous barchanoid-shaped dunes due to lateral grain size variability in a tidal inlet channel of the Danish Wadden Sea. Journal of Geophysical Research: Earth Surface, 110(4), pp.1- 13. https://doi.org/10.1029/2004JF000180

Harris, J. M., \& Whitehouse, R. J. S. (2015). Marine scour : Lessons from Nature's laboratory. 201(2014), pp.19-31.

Hong, J., Chiew, Y., Asce, M., Yeh, P., \& Chan, H. (2017). Evolution of Local Pier- Scour Depth with Dune Migration in Subcritical Flow Conditions. Journal of Hydraulic Engineering, 143(4), pp.4016098-1-0401609811. https://doi.org/10.1061/(ASCE)HY.1943-7900.0001261 
Lv, P., Dong, Z., Narteau, C., \& Rozier, O. (2016). Morphodynamic mechanisms for the formation of asymmetric barchans: improvement of the Bagnold and Tsoar models. Environmental Earth Sciences, 75(3), pp.1-9. https://doi.org/10.1007/s12665-015-5083-2

Ma, X., Yan, J., \& Fan, F. (2014). Morphology of submarine barchans and sediment transport in barchans fields off the Dongfang coast in Beibu Gulf. Geomorphology, 213, pp.213-224. https://doi.org/10.1016/j.geomorph.2014.01.010

Margalit, J. (2017). Development of natural seabed forms and their interaction with off shore wind farms. Technical University of Denmark.

Mayall, R. O., Byrne, B. W., Burd, H. J., Mcadam, R. A., \& Cassie, P. (2019). Modelling of foundation response to scour and scour protection for offshore wind turbine structures. In Y. Keh-Chia (Ed.), Scour and Erosion IX: Proceedings of the 9th International Conference on Scour and Erosion (ICSE 2018) pp. 405413.

Noormets, R., Ernstsen, V. B., Bartholomä, A., Flemming, B. W., \& Hebbeln, D. (2006). Implications of bedform dimensions for the prediction of local scour in tidal inlets : a case study from the southern North Sea. Geo-Marine Letters, 26, pp.165-176. https://doi.org/10.1007/s00367-006-0029-z

Omidyeganeh, M., Piomelli, U., Christensen, K. T., \& Best, J. L. (2013). Large-eddy simulation of flow over barchan dunes. Marine and River Dune Dynamics - MARID IV, (April), pp.191-198.

Pope, N. D., Widdows, J., \& Winsley, M. D. (2006) Estimation of bed shear stress using the turbulent kinetic energy approach - A comparison of annular flume and field data. Continental Shelf Research, 26, pp. 959970

Sumer, B. M., Fredsøe, J., \& Christiansen, N. (1992). Scour Around Vertical Pile in Waves. Journal of Waterway, Port, Coastal, and Ocean Engineering, 118(1), pp.15-31. https://doi.org/10.1061/(ASCE)0733950X(1992)118:1(15)

The Crown Estate. (2019). Offshore wind operational report: January - December 2018.

Van Lancker, V., Baeye, M., Francken, F., Legrand, S., Van den Eynde, D., Degrendele, K., De Mol, L. \& Roche, M., (2013). Impact evaluation of marine aggregate extraction through adaptive monitoring of bottom shear stress in bedform areas. Marine and River Dune Dynamics - MARID IV, (April), pp.271-276.

van Rijn, L. C. (1993). Principles of Sediment Transport in Rivers, Estuaries and Coastal Seas, Aqua Publications, Blokzijl, Netherlands.

Whitehouse, R. (1998). Scour at marine structures: A manual for practical applications.

https://doi.org/http://dx.doi.org/10.1680/sams.26551 